\title{
Analysis of the qPCR Assay Efficacy as Molecular Diagnostic in Patients with Chemotherapy and/or Antibiotic Therapy
}

Tiago César Gouvêa Moreira ${ }^{1,2 *}$
https://orcid.org/0000-0003-3362-7486

\section{Luciana de Andrade Agostinho ${ }^{1,2,3}$}

https://orcid.org/0000-0001-5604-8386

1 UNIFAMINAS University, Muriaé, Minas Gerais, Brazil; ${ }^{2}$ Cancer Hospital of Muriaé, Cristiano Varella Foundation, Muriaé, Minas Gerais, Brazil; ${ }^{3}$ Federal University of the State of Rio de Janeiro - UNIRIO, Neurology Postgraduate Program, Rio de Janeiro, Brazil.

Editor-in-Chief: Paulo Vitor Farago

Associate Editor: Sinvaldo Baglie

Received: 2019.08.07; Accepted: 2020.12.18.

*Correspondence: tiagooocesar@gmail.com; Tel.: +55-32-988579871 (T.C.G.M.).

\section{HIGHLIGHTS}

- RT-qPCR efficiency can vary according to $260 / 280$ ratio of samples analyzed.

- Chemotherapeutic drugs in the blood sample was not correlated with Ct variation (qPCR).

- The spectrophotometer determines a RNA quantification with 2.2 times higher than the fluorimeter.

- Antibiotics in the blood sample can be associated in $11.3 \%$ with the variability of $260 / 280$ ratio.

Abstract: High sensitivity of qPCR assay can be compromised by the presence of PCR inhibitors in samples analyzed. The aim of this study was to analyze the RT-qPCR assay efficiency considering the RNA quality/quantity and the presence of PCR inhibitors in patients with chemotherapy and/or antibiotic therapy. We analyzed 60 samples using RT-qPCR from individuals suspected of leukemia and 44 samples were quantified by fluorimetry and spectrophotometry. The efficiency of the RT-qPCR assay was evaluated comparing the threshold cycle (Ct) from tested samples and the standard curve. The 260/280 and 260/230 ratios, the presence of PCR inhibitors and the amount of sample (ng) used in the RT-qPCR reaction can be associated with $56.8 \%\left(R^{2}=0.56, p<0.05\right)$ in the $C t$ obtained. The decrease of the RT-qPCR efficiency can be explained in $42,8 \%$ due to the variation of the $260 / 280$ ratio $\left(R^{2}=0.42, p<0.05\right)$. The presence of antibiotics in the blood sample can be associated in $11.3 \%$ with the variability of $260 / 280$ ratio $\left(R^{2}=0.11, p<0.05\right)$. Presence of chemotherapeutic drugs in the blood sample was not correlated with $\mathrm{Ct}$ variation $(\mathrm{p}=0.17)$. The spectrophotometer determines a RNA quantification with 2.2 times higher than the fluorimeter $(\mathrm{t}=2.2, \mathrm{p}=0,03)$ and this difference is correlated with the $260 / 280$ ratio $\left(R^{2}=0.36, p<0.05\right)$. Samples with low purity had a reduction in the qPCR efficiency, although we did not observe false results.

Keywords: polymerase chain reaction/methods; Nucleic Acid synthesis inhibitors; RT-qPCR; fluorimetry; spectrophotometry. 


\section{INTRODUCTION}

Molecular diagnostics has shown great advances and an emergent growth [1]. Polymerase Chain Reaction (PCR) provided a great advance in the Molecular Biology field and the evolution to the quantitative PCR (qPCR) made the genetic researches and diagnostics easier and faster [2]. As qPCR assay has high sensitivity, the correct purification of nucleic acids is essential to obtain a sample without PCR inhibitors. The presence of PCR inhibitors may compromise the DNA polymerase enzyme efficiency as well as the primers hybridization [3] during the PCR reaction. Samples analyzed by molecular methods must be quantified and qualified before the PCR reaction, because the PCR step is more expensive than DNA/RNA extraction step. Nucleic acids can be quantified by two techniques, spectrophotometry and fluorimetry [4]. The spectrophotometry is able to quantify and qualify the samples, using the absorbance detected in different wavelengths. Fluorimetry is based on the detection of target-specific fluorescence, this integrated system is more sensitive than UV absorbance-based quantification [5]. The determination of correct concentrations in nanograms and the purity of samples investigated are important to reduce bias, costs and to increase the reliability of molecular diagnosis [6]. The aim of this study was to analyze the RT-qPCR assay efficiency used in molecular diagnosis in patients suspected of leukemia with chemotherapy and/or antibiotic therapy, considering the RNA quality, quantity and the presence of PCR inhibitors. Two measuring tools of nucleic acids quantity, as fluorimetry and spectrophotometry, were applied and had the results compared.

\section{MATERIAL AND METHODS}

All 60 participants came from the Hematology outpatient of the Cancer Hospital of Muriaé city, in Minas Gerais state. All patients were suspected of having leukemia. This project is approved by the Ethics Committee CEP - FAMINAS with CAAE: 62262316.7.0000.5105. The inclusion criterias were: individual with suspected leukemia based on their symptoms, indication of Leukemia genetic test and individuals older than 18 years. Two tubes of EDTA with peripheral blood were collected $(3 \mathrm{~mL})$, followed by RNA extraction using PureLink ${ }^{\circledR}$ Total RNA Blood Purification Kit and the RNA conversion to CDNA with the SuperScript IV Vilo Master Mix enzyme (Thermo Fisher Scientific). In 60 RNA samples analyzed, 44 were quantified using two equipments, the Qubit 3.0 Fluorometer ${ }^{\circledR}$ and Nanodrop One®. The efficiency of the RT-qPCR technique was evaluated comparing the $\mathrm{Ct}$ value of tested samples (considering the amount of nucleic acid inserted in the PCR reaction) with the Ct value obtained from a standard curve. Standard curve was constructed with a reference sample, without inhibitors, in different points of RNA: 50, 45, 40, 35, 30, 25 and 20 ng/assay. Each point was made in duplicate and the target was the ABL1 constitutive gene (validated with HL60 lineage cells). It is important to mention that $\mathrm{Ct}$ deviation is the difference of $\mathrm{Ct}$ between the samples and the standard curve and $\mathrm{Ct}$ variation is only the value obtained from qPCR reactions. For RT-qPCR analysis, TaqMan hydrolysis probes were used for detection the ABL1 constitutive gene (Hs99999002_mH, from Thermo Fisher Scientific). Our study considered only the ABL1 gene to avoid any interference of the presence of the (9:22) translocation in positive samples. A known sample, HL60 lineage, kindly ceded by UNICAMP, was used to validate the $A B L$ assay and the standard curve was performed. The following qPCR cycle used was: 1 cycle of $95^{\circ} \mathrm{C}$ for 20 seconds (Hold Stage) and 40 cycles of $95^{\circ} \mathrm{C}$ for 1 second and $60^{\circ} \mathrm{C}$ for 20 seconds (PCR Stage). Before analyze the samples, a sensitivity test was performed in the both equipments used to RNA quantification. A 5-point dilution (4:6) of a known sample, without PCR inhibitors, was tested. The difference between the $\mathrm{Ct}$ value of samples tested and the $\mathrm{Ct}$ values observed in the standard curve was used to suggest the efficiency of qPCR according to Stolovitzky, (1996) [7]. According to Svec and coauthors, the standard curve with 1:10 dilution had usually 3 cycles of difference between the points, and a high Ct deviation must be investigated. The ability to estimate the $\mathrm{Ct}$ values associated with the amount of nucleic acids used (ng/assay) is presented by factor (R2) [8] and the prediction value (R2) reduces when the efficiency of the qPCR reaction also decreases. We considered as PCR inhibitors when patients were using hormones $[9,10]$, metabolites [11,12] and anticoagulant substances for treatment [11] in the same moment of the blood collection to diagnostic test. The information about the PCR inhibitors and the drugs used in patients were obtained from the Medical Reports in our hospital. Chemotherapeutic drugs analyzed were splited in Hydrea ${ }^{\circledR}$ and Tyrosine Kinase Inhibitors (TKIs $\AA$ ), as Imatinib $\AA$, Dasatinib $\AA$ and Nilotinib $\AA$. The antibiotics were not splited in groups, we specified only the presence of them. Hydrea ${ }^{\circledR}$ and Imatinib® were also analyzed by spectrophotometry and by fluorimetry with similar concentrations observed in the plasma of patients treated. The drugs were diluted in deionized water according to the daily dosage used in the patients. Hydrea® (500 $\mathrm{mg}$ ) and Imatinib® $(400 \mathrm{mg})$ were firstly diluted in $500 \mathrm{~mL}$. Then, a second dilution was done (1:10) getting a final concentration of $0.1 \mathrm{mg} / \mathrm{mL}$ of $\mathrm{Hydrea} \AA$ and $0.08 \mathrm{mg} / \mathrm{mL}$ of Imatinib®. We also investigated the 
presence of residual genomic DNA after the RNA extraction from 31 randomly selected samples. To analyze the residual DNA we quantified these samples by fluorimetry using the Qubit TM dsDNA HS Assay Kit (Thermo Fisher Scientific). Data were analyzed with IBM SPSS Statistics program (version 17). Values of $p<0.05$ were considered statistically significant. The normality test was performed with Shapiro Wilk. For the correlation of possible PCR inhibitors and the qPCR efficiency, we used the Spearman's rho and Multiple regression tests. For the comparison between the results obtained from two techniques to quantify the RNA, the t-test of paired samples was applied.

\section{RESULTS}

Peripheral blood samples were obtained from 60 suspected leukemia patients living in Minas Gerais state, Brazil, from the Cancer Hospital in Muriaé city. To analyze the sensitivity of the equipments used in this study we analyzed a RNA reference sample in five dilution points by fluorimetry and by spectrophotometry. To predict a standard curve of quantification with high sensitivity in each equipment we used the first point measured of sample. Then, the values between the measured RNA quantity and the expected quantity (predicted in standard curve) were compared to obtain the sensitivity of each technique (Figure 1).
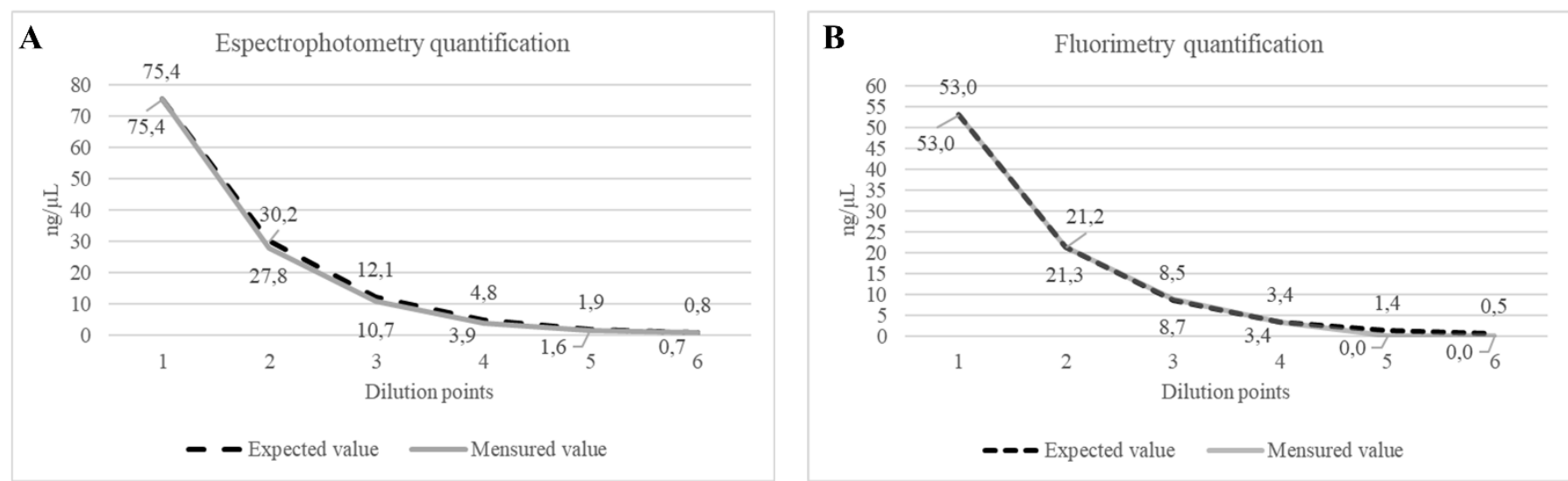

Figure 1. Difference between the real RNA quantification and the expected measure. (a) Spectrophotometry sensitivity test; (b) Fluorimetry sensitivity test.

In both techniques, spectrophotometry and fluorimetry, were similar with $99 \%(p<0.05)$ when had the predicted and measured RNA quantity compared. RNA samples $(n=44)$ had a median of $77.47 \mathrm{ng} / \mu \mathrm{L}$ (Minimum: 12.55, Maximum: 433.64) by spectrophotometry, and $72.55 \mathrm{ng} / \mu \mathrm{L}$ (Min.: 4.26, Max.: 494) by fluorimetry. The 260/280 ratio had a median of 2.02 (Min.: 1.81, Max: 2.10) and 260/230 ratio had a median of 1.83 (Min.: 0.43 , Max.: 2.22). The spectrophotometry estimates the RNA quantity with two times higher than fluorimetry $(\mathrm{t}=2.2, \mathrm{p}=0.03)$. The difference observed between fluorimetry and spectrophotometry can be inversely correlated in $36.1 \%$ with the $260 / 280$ ratio of samples $\left(R^{2}=-0.361, p=0.008\right)$. The standard curve with a known sample was used as reference parameter to analyze the qPCR efficiency of samples tested (Figure 2) when the Ct are compared. 


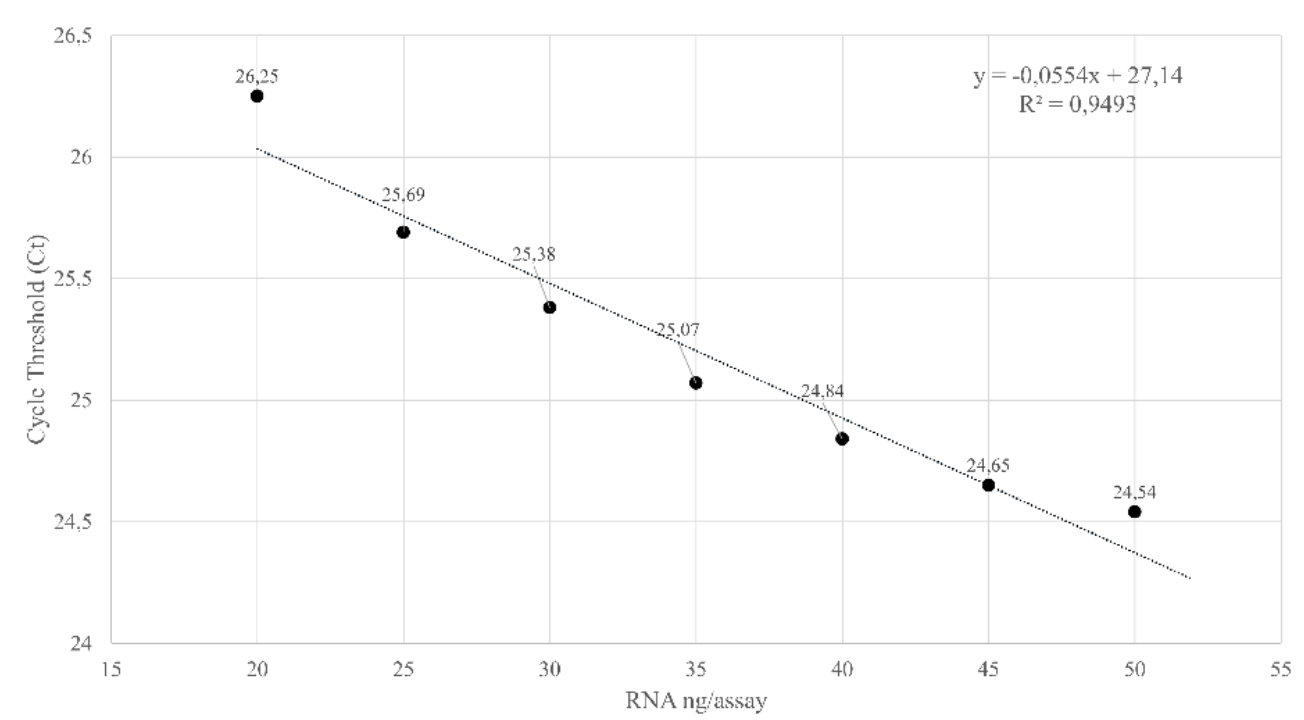

Figure 2. Standard curve with a known sample without PCR inhibitors in 7 points.

Regarding the 60 samples investigated, 32 patients were using chemotherapeutics drugs, 23 of them $(71,9 \%)$ using Hydrea ${ }^{\circledR}$ and nine were using $(28,1 \%)$ TKIs ${ }^{\circledR}$ when the blood was collected (Figure 3 ).

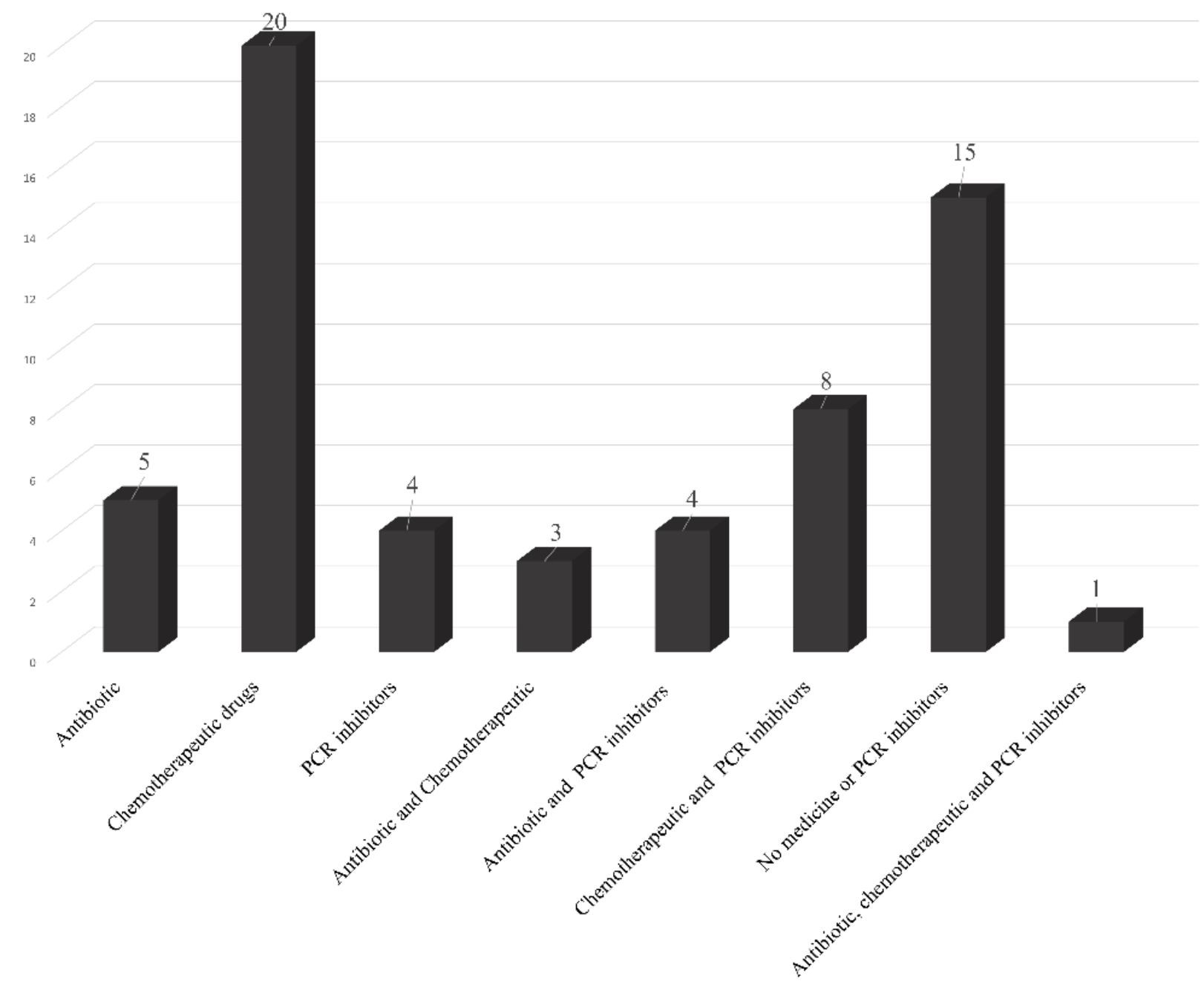

Figure 3. Substances present in the samples during blood collection.

The Ct observed in the samples analyzed, considering the RNA amount and the presence of drugs and/or PCR inhibitors, were compared with the Ct of the standard curve (Figures $4 \mathrm{~A}, \mathrm{~B}, \mathrm{C}, \mathrm{D}, \mathrm{E}, \mathrm{F}, \mathrm{G}$ ) to determine the $\mathrm{Ct}$ deviation. The patient that used chemotherapeutic drug, antibiotic and had PCR inhibitors in sample, in the same moment, was excluded of the statistical analysis $(n=1)$. 

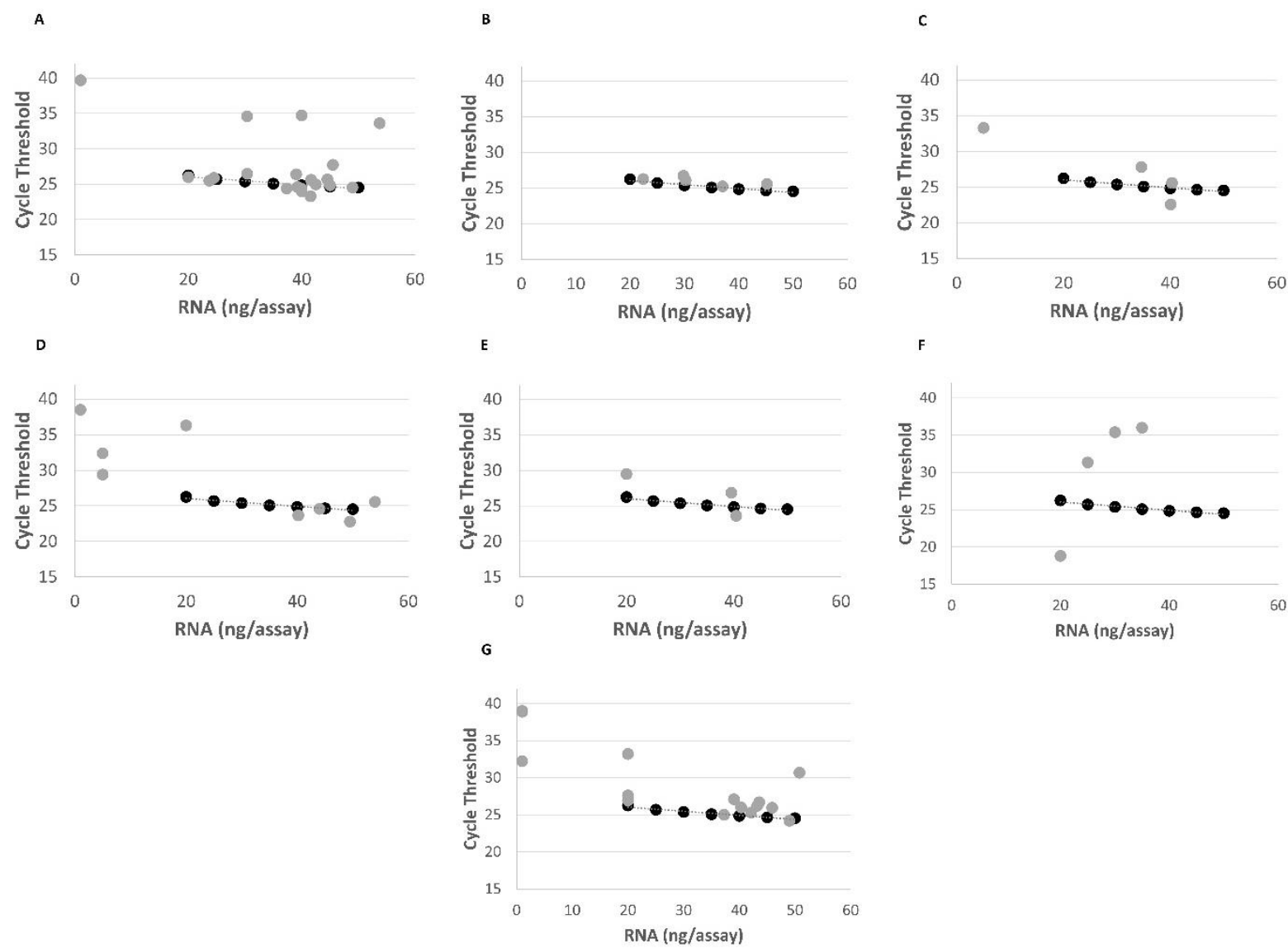

Figure 4. Correlation between $\mathrm{Ct}$ variation and the amount of samples (ng/assay) with chemotherapeutic drugs, antibiotics and PCR inhibitors at the time of blood collection and the standard curve used as reference. (a) Chemotherapeutic drugs, (b) PCR inhibitors, (c) Antibiotics, (d) Chemotherapeutic drugs and PCR inhibitors, (e) Antibiotics and chemotherapeutic drugs, (f) Antibiotics and PCR inhibitors, (g) Pure sample.

The presence of antibiotics in the blood sample can be slightly associated in $11.3 \%$ with the variability of $260 / 280$ ratio $\left(R^{2}=0.11 p<0.05\right)$. And the decrease of the $R T$-qPCR efficiency (Ct deviation) can be explained in $42,8 \%$ due to the variation of the $260 / 280$ ratio $\left(R^{2}=0.42, p<0.05\right)$. The Ct variation of the samples was associated with the amount of sample inserted in the PCR reaction in $54.6 \%\left(R^{2}=0.54, p<0.05\right)$. When this same analysis was carried out with the variables: presence PCR inhibitors and 260/280 and 260/230 ratios jointly, the association was $56,8 \%\left(R^{2}=0.56, p<0.05\right)$. The presence of chemotherapeutic drugs in the blood sample was not correlated with $\mathrm{Ct}$ variation $(\mathrm{p}=0.17)$. PCR inhibitors present in the blood of the patients during blood collection and showed no correlation with the Ct deviation of the standard curve $(p=0.5)$. Hydrea $\AA$ and Imatinib® were analyzed by spectrophotometry in RNA mode. At least one of the three wavelengths used to calculate the $260 / 280$ and $260 / 230$ ratios, were also observed to detect the presence of these drugs (Figure 5). 

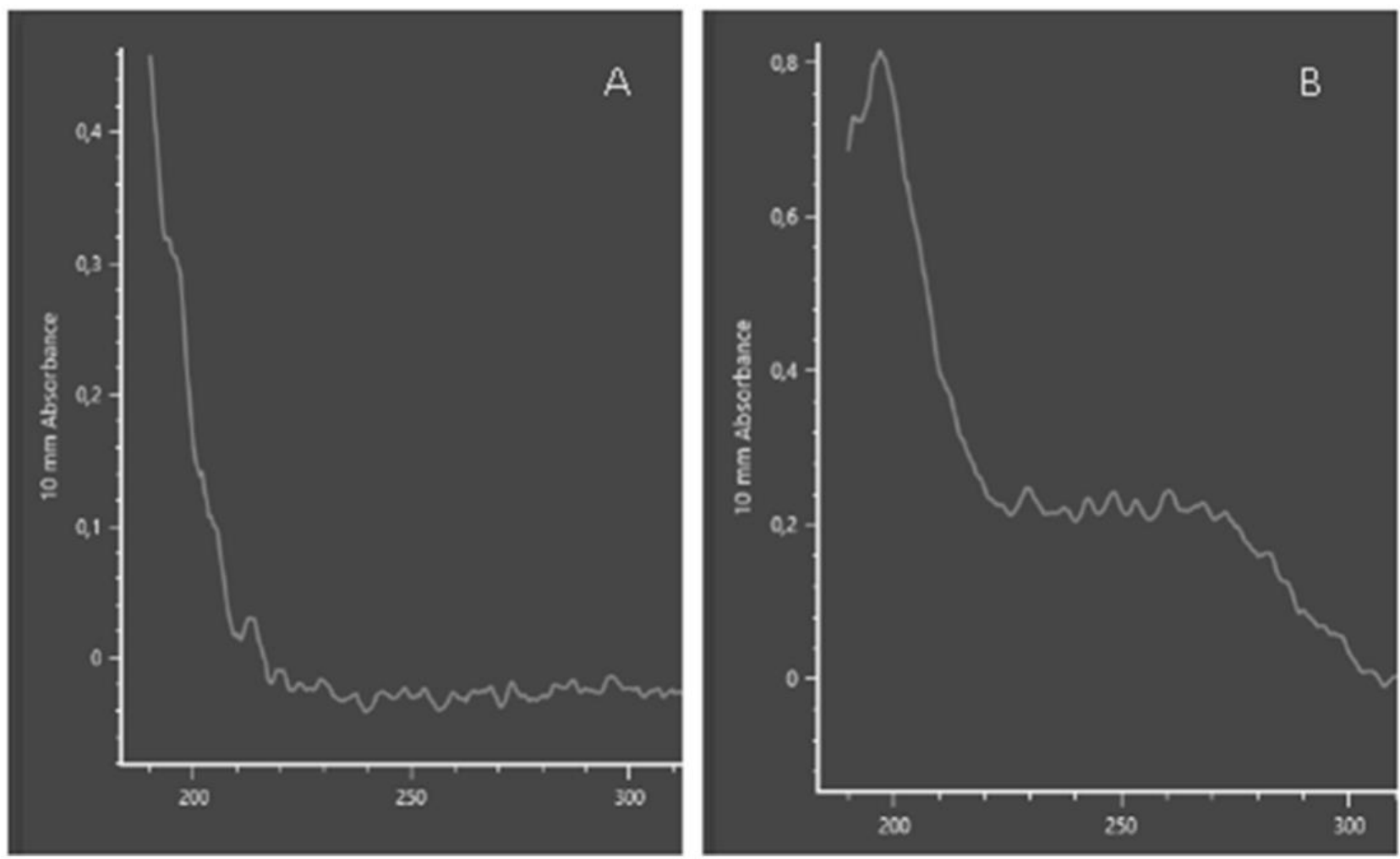

Figure 5. Hydrea® $(0.1 \mathrm{mg} / \mathrm{mL})(\mathrm{A})$ and Imatinib $(0.08 \mathrm{mg} / \mathrm{mL})(B)$ analyzed by spectrophotometry.

Imatinib® was analyzed by spectrophotometry at two different concentrations $(0.8$ and $0.08 \mathrm{mg} / \mathrm{mL})$, and the RNA quantity observed were $1496.5 \mathrm{ng} / \mu \mathrm{L}$ and 12.04 respectively. Hydrea ${ }^{\circledR}$ did not show any RNA quantity (Table 1). Imatinib® and Hydrea ${ }^{\circledR}$ were also quantified by fluorimetry with an RNAspecific kit, however, Hydrea ${ }^{\circledR}$ showed no quantification at any concentration. Imatinib® in the first dilution quantified 2.1 $\mathrm{ng} / \mu \mathrm{L}$ of RNA (Table 1). It is important to mention that no RNA molecule was inserted in these samples analyzed.

Table 1. RNA Quantification of chemotherapeutic drugs by spectrophotometry.

\begin{tabular}{ccccc}
\hline \multicolumn{2}{c}{ Quantification of chemotherapy drugs with Nanodrop and Qubit } & \multicolumn{3}{c}{ Nanodrop } \\
\cline { 2 - 4 } Dilution of chemotherapy drugs & $\begin{array}{c}\text { Concentration }(\mathrm{ng} \\
/ \mu \mathrm{L})\end{array}$ & $260 / 280$ & $260 / 230$ & Qubit \\
\hline Hydrea $(1 \mathrm{mg} / \mathrm{mL})$ & 0.135 & -1.825 & 0.068 & 0 \\
Hydrea $(0,1 \mathrm{mg} / \mathrm{mL})$ & -0.573 & 1.228 & -0.549 & 0 \\
Imatinib $(0,8 \mathrm{mg} / \mathrm{mL})$ & 1.496 .552 & 1.226 & 1.118 & 2.1 \\
Imatinib $(0,08 \mathrm{mg} / \mathrm{mL})$ & 12.049 & 1.388 & 1.162 & 0 \\
\hline
\end{tabular}

To verify the purity of RNA isolated, we investigated by fluorimetry the presence of residual DNA in 31 RNA samples after the extraction process. We observed residual DNA with an average of $20,51 \pm 12,49 \mathrm{ng} / \mu \mathrm{L}$ in our RNA samples (Table 2). And the difference between the quantification determined by fluorimetry and spectrophotometry in these 31 samples had an average of $10,23 \pm 27,11 \mathrm{ng} / \mu \mathrm{L}$. 
Table 2. Residual DNA determined in samples with RNA extracted $(n=31)$.

\begin{tabular}{|c|c|c|c|c|c|c|}
\hline Samples & $\begin{array}{l}\text { Nanodrop } \\
(\mathrm{ng} / \mu \mathrm{L})\end{array}$ & $260 / 280$ & $260 / 230$ & 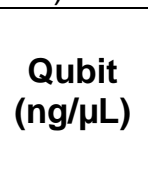 & $\begin{array}{c}\text { Difference } \\
\text { between } \\
\text { Nanodrop and } \\
\text { Qubit (ng } / \mu \mathrm{L})\end{array}$ & $\begin{array}{c}\text { Residual DNA } \\
\text { in RNA } \\
\text { samples }\end{array}$ \\
\hline $002.1 \mathrm{R}$ & 264,09 & 2,03 & 1,88 & 174 & 90,09 & 13,3 \\
\hline 005.2 R & 137,62 & 2 & 2,04 & 136 & 1,62 & 8,42 \\
\hline $007.1 \mathrm{R}$ & 51,74 & 1,94 & 1,91 & 38,8 & 12,94 & 22,9 \\
\hline 008.2 R & 46,28 & 1,96 & 1,51 & 28,4 & 17,88 & 20,5 \\
\hline 009.2 R & 77,82 & 2,02 & 1,79 & 77 & 0,82 & 9,72 \\
\hline $010.2 \mathrm{R}$ & 70,14 & 1,96 & 1,84 & 51,3 & 18,84 & 22,2 \\
\hline $013.2 \mathrm{R}$ & 226,91 & 2,04 & 2,11 & 251 & $-24,09$ & 25 \\
\hline $014.3 \mathrm{R}$ & 216,53 & 2,06 & 2,12 & 150 & 66,53 & 9,77 \\
\hline $015.1 \mathrm{R}$ & 433,64 & 2,09 & 1,94 & 452 & $-18,36$ & 8,99 \\
\hline $016.1 \mathrm{R}$ & 32,48 & 1,92 & 1,64 & 12,1 & 20,38 & 35,1 \\
\hline $017.1 \mathrm{R}$ & 53,38 & 1,97 & 1,34 & 50,5 & 2,88 & 13,4 \\
\hline $019.1 \mathrm{R}$ & 50,87 & 2,03 & 1,81 & 62,3 & $-11,44$ & 12,7 \\
\hline $020.1 \mathrm{R}$ & 98,86 & 2,05 & 2,08 & 111 & $-12,14$ & 10,1 \\
\hline $021.2 \mathrm{R}$ & 138 & 2,05 & 1,3 & 145 & -7 & 12,5 \\
\hline $023.1 \mathrm{R}$ & 308,25 & 2,05 & 2,08 & 382 & $-73,75$ & 10,1 \\
\hline $026.1 \mathrm{R}$ & 316 & 2 & 2 & 306 & 10 & 54 \\
\hline $027.1 \mathrm{R}$ & 87,01 & 2,01 & 1,62 & 72,4 & 14,61 & 20,2 \\
\hline $029.1 \mathrm{R}$ & 127,76 & 1,99 & 1,34 & 118 & 9,76 & 42,9 \\
\hline $031.1 \mathrm{R}$ & 56,94 & 1,86 & 1,81 & 10,4 & 46,54 & 0 \\
\hline $033.1 \mathrm{R}$ & 165,83 & 2,05 & 2,04 & 160 & 5,83 & 36,5 \\
\hline $034.1 \mathrm{R}$ & 77,13 & 1,97 & 1,78 & 55 & 22,13 & 33 \\
\hline $035.2 \mathrm{R}$ & 49,22 & 1,95 & 1,5 & 36,3 & 12,92 & 8,19 \\
\hline 036.2 R & 55,99 & 1,99 & 1,88 & 37,2 & 18,79 & 27,1 \\
\hline $037.2 \mathrm{R}$ & 24,01 & 1,88 & 1,7 & 9,94 & 14,07 & 19,2 \\
\hline $039.2 \mathrm{R}$ & 83,12 & 2,04 & 1,18 & 73 & 10,12 & 26,8 \\
\hline $040.2 \mathrm{R}$ & 68,7 & 2,04 & 1,97 & 55 & 13,7 & 23,1 \\
\hline $041.2 \mathrm{R}$ & 219,99 & 2,06 & 2 & 203 & 16,99 & 38,1 \\
\hline $042.1 \mathrm{R}$ & 66,25 & 1,97 & 1,88 & 49,9 & 16,35 & 25,8 \\
\hline $043.1 \mathrm{R}$ & 58,52 & 2,1 & 1,44 & 54 & 4,52 & 12,9 \\
\hline $044.1 \mathrm{R}$ & 12,55 & 1,85 & 0,93 & 5 & 7,55 & 3,29 \\
\hline $045.1 \mathrm{R}$ & 160,26 & 2,04 & 2,14 & 152 & 8,26 & 30,3 \\
\hline Mean & 123,7 & 2,0 & 1,8 & 113,5 & 10,23 & 20,51 \\
\hline
\end{tabular}

\section{DISCUSSION}

The high quality of samples before the genetic analysis is important to obtain a reliable result [4]. The presence of PCR inhibitors in samples may result in decreased sensitivity or even false negative results [3]. Our RNA samples had high quality as 260/280 ratio with average of 2 and 260/230 with 1.8 [13]. When the $260 / 280$ ratio is low it may indicate the presence of phenol, proteins and other contaminants that absorb mainly at $280 \mathrm{~nm}$ in the spectrophotometry. The 260/230 ratio usually ranges from 1.8 and 2.2 for RNA, and low values may indicate the presence of ethanol. O'Neill and coauthors [5] reported that Qubit ${ }^{\circledR}$ is a reference quantification method in genetic studies, since it provides more accurate results than spectrophotometry because it can be specific to determine RNA, DNA and proteins using different kits. However, fluorimetry does not provide the quality of nucleic acids as well as spectrophotometry. According to the Nanodrop equipment user guide [13], it is able to detect RNA samples with a range of $1.6 \mathrm{ng} / \mu \mathrm{L}$ to $22,000 \mathrm{ng} / \mu \mathrm{L}$. In this study, only one sample had the quantification higher when analyzed by fluorimetry when compared with the value observed by spectrophotometry [14]. Haque and coauthors [6] compared the quantification of DNA 
samples by spectrophotometry and two fluorometric quantification methods, as PicoGreen $\AA$ and $\mathrm{qPCR}$, and observed that the performance of spectrophotometric DNA quantification was the most concordant with reference samples among the three methods evaluated. Ponti and coauthors [15] concluded that the combination of fluorimetry and spectrophotometry routinely would be ideal. The fluorimetry is more accurate in quantification of samples and the spectrophotometry can qualify the samples showing the presence of PCR inhibitors. In our study the samples analyzed by spectrophotometry were quantified with 2 times more than fluorimetry $(\mathrm{t}=2,2 ; \mathrm{p}=0,03)$. The chemotherapeutic drugs Hydrea $\AA$ and TKIs $\AA$ are used in patients with suspected and leukemia patients, respectively [16]. Therefore, for the correct molecular diagnosis of these patients, it is necessary to analyze these drugs as possible interferers in the quality of the sample used in RT-qPCR assay. The presence of PCR inhibitors, $260 / 280$ and $260 / 230$ ratios and the amount of sample (ng) used in qPCR reaction can be associated with $56.8 \%\left(R^{2}=0.56, p<0.05\right)$ in the Ct variation. Some PCR inhibitors present in clinical samples (blood, plasma and serum) have already been described, such as: hemoglobin, hormones, bile salts, anticoagulants, IgG, lactoferrin, urea, among others [9-12]. In a literature review conducted in this study, no study was found reporting antibiotics or chemotherapeutic drugs as possible interferers of the quality RNA extracted samples and consequently of the qPCR efficiency. The estimation of qPCR efficiency can be performed by means of a standard curve with samples at different dilutions with a known and without inhibitors sample. To evaluate qPCR efficiency, a slope with -3.33 cycles [8] is expected at each 10-fold dilution of the standard curve. The 260/280 ratio was associated to the $\mathrm{Ct}$ deviation $\left(R^{2}=0.42, p<0.05\right)$. The presence of antibiotics in the blood sample can be associated in $11.3 \%$ with the variability of $260 / 280$ ratio $\left(R^{2}=0.11 p<0.05\right)$. The presence of phenol, proteins or other possible substances that alter this factor may inhibit the PCR technique. PCR inhibitors described by Schrader and coauthors [3] are present in the blood of the patients during blood collection and showed no correlation with the Ct deviation of the standard curve $(p=0.5)$. Imatinib absorbance showed peaks at $200 \mathrm{~nm}$ and from 250 to $280 \mathrm{~nm}$, the same range used to qualify and quantify DNA/RNA samples (230, 260 and $280 \mathrm{~nm})$. Another study that also analyzed the absorbance of this drug, observed a similar absorption spectrum, with detection at 200, 250 and $270 \mathrm{~nm}$ [17]. Hanna and Gairani [18] also analyzed the absorption spectrum of Imatinib® mesylate and identified that the highest absorbance point of the drug was between 260 and $270 \mathrm{~nm}$. There is a greater specificity of the method of quantification by fluorimetry than by spectrophotometry [5]. After extracting DNA from human tissue, Simbolo and coauthors (2013) identified the presence of residual RNA and $260 / 230$ ratio abnormal [14]. Our study observed $20,51 \pm 12,49 \mathrm{ng} / \mu \mathrm{L}$ of residual DNA in RNA extracted samples and the difference of the quantity obtained by Nanodrop and Qubit was $10,23 \pm 27,11 \mathrm{ng} / \mu \mathrm{L}$. The RNA extraction kit can extract genomic DNA (gDNA) and not only RNA (target molecule) from the samples. SEE and coauthors [19] compared four RNA extraction and all of them presented gDNA in the extracted samples and a DNase I endonuclease was used to remove DNA of samples. Although DNase removes gDNA, there is a risk of degradation of the target molecule, RNA. Tesena and coauthors [20] also identified the presence of gDNA in all three methods of extracting RNA from gastric tumor tissue (TRIzol TM, GENEzol TM and MiniPrep ${ }^{\mathrm{TM}}$ ). However, the TRIzol TM method demonstrated large amounts of gDNA and protein contamination, and the amount of RNA was not sufficient for the achievement of RT-qPCR. Additional washing steps were required to remove these contaminants to obtain a clean PCR reaction. Accordingly Terry and coauthors [21] the nucleic acid extraction kit removes all qPCR interferents, such as: inhibitors of the technique and the contamination of RNA or DNA, leaving the isolated molecule intact, pure and with a concentration of the ideal material for the analysis. The chemotherapeutic drugs, antibiotics and PCR inhibitors present in the analyzed samples should be also removed after extraction of the genetic material. The efficiency of PCR is extremely important in the diagnosis of patients, since when affected, it can directly impact the correct diagnosis of them. For a high efficiency of the technique, some factors such as sample purity, primer characteristics and amplicon lengths should also be taken into account [22]. PCR inhibitors and inadequate quantification of the samples to be analyzed can have a direct impact on the diagnosis, prognosis, treatment and quality of life of the patients, since these inhibitors can lead to false results [6,3] and higher costs. To perform the molecular diagnosis, it is necessary to validate the three steps: preanalytical, analytical and post-analytic. About $70 \%$ of analytical errors reflect in the pre-analytical phase, although it is the cheapest step, such as blood collection and sample preparation for analysis [23]. Many studies focus on analytical errors in molecular diagnosis, however, preanalytical variables such as storage, transport, stability and extraction of genetic material have great impacts on any molecular diagnosis [24]. 


\section{CONCLUSION}

To obtain a reliable diagnosis is extremely important that the target molecule is pure, without PCR inhibitors and accurate quantification of genetic material for analysis. In addition, the misdiagnosis of these patients will directly influence their treatment, prognosis and quality of life. The difference between the two quantification methods, spectrophotometry and fluorometry, can be explained by the variation of the factor 260/280 purity and the presence of residual DNA in the purified RNA samples. The fluorimetry showed greater sensitivity in the quantification of RNA samples when compared to the spectrophotometry. The presence of PCR inhibitors, 260/280 and 260/230 ratios and RNA quantity in nanograms/assay can explain the $\mathrm{Ct}$ variation. The presence of Imatinib in the samples can interfere in the qualification/quantification of samples when analyzed by spectrophotometry. In this study, the presence of antibiotics in the blood can be associated with the variability of $260 / 280$ ratio, but not with the RT-qPCR efficiency (Ct deviation). The presence of chemotherapeutic drugs in the samples was not correlated with Ct variation. According to the validation process of each laboratory, a reliable interval of Ct must be determined to confirm the results as positive or negative. Therefore, the samples must be pure and without contaminants. It is important to know which substances can interfere in the diagnostic results.

Funding: This research received no external funding.

Acknowledgments: We would like to thank Profa ${ }^{a}$. Dr. Katia Borgia Barbosa Pagnano of the Clinical and Molecular Hematology of UNICAMP / SP for having kindly ceded the lineages with the presence of the fusions for which our tests were validated. And to the Hematologists Dr. Maurício Drummond Alves, Dr. Vânia Monteiro Kussumi and Dr. Rafaella Cabral Samico for the contribution of the clinical part of the patients involved.

Conflicts of Interest: The authors declare no conflict of interest.

\section{REFERENCES}

1. Barra GB, Caixeta MCSASB, Costa PGG, Sousa CF, Velasco LFR. Diagnóstico molecular - passado, presente e futuro. Rev. Bras. Anal. Clin. 2011;43(3):254-60.

2. Oliveira TMS, Miranda LMS. PCR em tempo real: métodos e aplicações, 2010. Departamento de Biologia da Universidade de Aveiro; 2010.

3. Schrader C, Schielke Um, Ellerbroek G, Johne R. PCR inhibitors- occurrence, properties and removal. J Appl Microbiol. 2012;113(5):1014-26.

4. Pacific Biosciences [Internet]. California (USA). Spittle K et al. Sample Quality - Effects of Contaminants on SMRTbell Library Preparation and Sequencing. Pacific Biosciences; 2012.

5. O'Neill M, McPartlin J, Arthure K, Riedel S, McMillan Nd. Comparison of the TLDA with the Nanodrop and the reference Qubit system. Jornal of Physics: Conference Series. 2011;307(1)1-6.

6. Haque KA, Pfeiffer RM, Beerman MB, Struewing JP, Chanock SJ, Bergen AW. Performance of HighThroughput DNA Quantification Methods. BMC Biotechnology. 2003 Oct; 3:20.

7. Stolovitzky L, Cecchi L. Efficiency of DNA replication in the polymerase chain reaction. Proc Natl Acad Sci USA. 1996 Nov;93(23):12947-52.

8. Svec D, Tichopad Um, Novosadova V, Pfaffl MW, Kubista M. How Good Is a PCR Efficiency Estimate: Recommendations for Precise and Robust qPCR Efficiency Assessments. Biomolecular Detection and Quantification. 2015 Mar;11(3):9-16.

9. Yedidag EN, Koffron AJ, Mueller KH, Kaplan B, Kaufman DB, Fryer JP et al. Acyclovir triphosphate inhibits the diagnostic polymerase chain reaction for cytomegalovirus. Transplantation. 1996;62:238-42.

10. Burkardt HJ. Standardization and quality control of PCR analyses. Clin Chem Lab Med . 2000;38:87-91.

11. Rossen L, Norskov P, Holmstrom K, Rasmussen OF. Inhibition of PCR by components of food samples, microbial diagnostic assays and DNA-extraction solutions. Int J Food Microbiol. 1992;17:37-45.

12. Radstrom P, Knutsson R, Wolffs $P$, Lovenklev M, Lofstrom C. Pre-PCR processing: strategies to generate PCRcompatible samples. Mol Biotechnol. 2004;26,133-46.

13. Thermo Fisher Scientific. Nanodrop One user Guide- NanoDrop Micro-UV/Vis Spectrophotometers. 1st ed., Oct. 2015.

14. Simbolo M, Gottardi M, Corbo V, et al. DNA Qualification Workflow for Next Generation Sequencing of Histopathological Samples. PLOS ONE. 2013 Mar;8(6).

15. Ponti G, Maccaferri M, Manfredini M, Kaleci S, Mandrioli M, Pellacani G, et al. The value of fluorimetry (Qubit) and spectrophotometry (NanoDrop) in the quantification of cell-free DNA (cfDNA) in malignant melanoma and prostate cancer patients. Clin Chim Acta. 2018 Apr;479:14-9. 
16. Bandeira FMGC, Jaqueline CP, Eduardo JC, Bezerra I, Araújo AS, Mello, et al. Hidroxiuréia em pacientes com síndromes falciformes acompanhados no Hospital Hemope, Recife, Brasil. Rev Bras de Hematol e Hemoter. 2004 Ago;26(3):189-94.

17. Ajimura TO, Gaitani CM. Análise do mesilato de Imatinibe em plasma empregado a eletroforese capilar [Internet]. Faculdade de Ciências Farmacêuticas de Ribeirão Preto- Universidade de São Paulo; 2010 [Cited 2018 Oct. 7]. Availables from: http://www.teses.usp.br/teses/disponiveis/60/60137/tde-01122010- 135234/pt-br.php.

18. Hanna TB, Gaitani CM. de. Avaliação do perfil in vitro de dissolução de comprimidos de mesilato de Imatinibe empregando a cromatografia líquida de alta eficiência [Internet]. Faculdade de Ciências Farmacêuticas de Ribeirão Preto- Universidade de São Paulo; 2010 [Cited 2018 Oct. 7]. Availables from: http://www.teses.usp.br/teses/disponiveis/60/60137/tde-29102010-113037/pt-br.php.

19. See MJ, Staggs SE, Dubey JP, Villegas EN. Avaliação de quatro métodos de extração de RNA para análise da expressão gênica de oocistos de Cryptosporidium parvum e Toxoplasma gondii. J Microbiol Methods. 2012 Jun;89(3):185-92.

20. Tesena P, Korchunjit W, Taylor J, Wongtawan T. Comparison of Commercial RNA Extraction Kits and qPCR Master Mixes for Studying Gene Expression in Small Biopsy Tissue Samples from the Equine Gastric Epithelium. J Equine Sci. 2017 Dec;28(4):135-41.

21. Terry CF, Harris N, Parkes HC. Detection of genetically modified crops and their derivatives: critical steps in sample preparation and extraction. J AOAC Int. 2002 May-Jun;85(3):768-74.

22. Yuan JS, Reed A, Chen M, Stewart CN Jr. Statistical analysis of real-time PCR data. BMC bioinformatics. 2006 Fev;7:85.

23. Najat D. Prevalence of Pre-Analytical Errors in Clinical Chemistry Diagnostic Labs in Sulaimani City of Iraqi Kurdistan. Plos One. 2017;12(1).

24. Anwar A, Wan G, Chua KB, August JT, Too HP. Evaluation of pre-analytical variables in the quantification of dengue virus by realtime polymerase chain reaction. J Mol Diagn. 2009 Jan;11(6):537- 42.

(C) 5 (1) 2021 by the authors. Submitted for possible open access publication under the terms and
conditions of the Creative Commons Attribution (CC BY NC) license
(https://creativecommons.org/licenses/by-nc/4.0/). 